\title{
FORMULASI KEPEMIMPINAN PENDIDIKAN (Perspektif Teori Kepemimpinan dalam Dokrtin Al-Qur'an)
}

\author{
Shoni Rahmatullah Amrozi \\ Institut Agama Islam Negeri Jember \\ shonirahmatullah@gmail.com
}

\begin{abstract}
Abstrak
Ketika seluruh dunia tenggelam dalam arus kebohongan, hilangnya martabat manusia, jauh dari cahaya tauhid, dan komunitas sosial, politik, ekonomi, budaya dan agama, terutama ketika dunia Arab sangat rapuh dan gelisah, muncul seorang tokoh besar dalam sejarah panjang manusia. Dia membawa obor perubahan dari kegelapan menjadi cahaya terang dalam kehidupan. Dia memimpin masyarakat yang kacau menjadi masyarakat yang terbimbing dan terdidik, terlebih lagi membebaskan orang Arab dari politeisme menjadi monoteisme. Dia adalah Nabi Muhammad yang terkenal sebagai pembawa rahmatallil'alamin. Periode kepemimpinan Nabi Muhammad adalah cikal bakal pembentukan peradaban Islam. Krisis terbesar di dunia saat ini adalah krisis keteladanan. Krisis ini lebih kuat daripada krisis energi, kesehatan, makanan, transportasi dan air. Karena tidak adanya pemimpin visioner, kompeten, dan memiliki integritas tinggi maka masalah air, konservasi hutan, kesehatan, pendidikan, sistem peradilan, dan transportasi akan menjadi semakin parah. Akibatnya, semakin banyak biaya perawatan kesehatan yang sulit untuk dijangkau, manajemen transportasi semakin kacau, pendidikan kehilangan kesadaran akan karakter mulia yang berorientasi belas kasih, sungai dan air tanah semakin tercemar dan sampah menumpuk di mana-mana. Dalam hal ini, di antara masalah yang dialami oleh dunia Muslim, termasuk Indonesia, sebagai negara terbesar ketiga di dunia. Oleh karena itu, kepemimpinan Nabi Muhammad adalah tolak ukur yang harus diikuti oleh semua manusia dalam hal memproyeksikan pola kepemimpinan, karena kepemimpinan yang diajarkanya akan mengarahkan orang untuk menjadi pemimpin yang dihormati, dicintai dan diikuti oleh semua orang.
\end{abstract}

Kata kunci: kepemimpinan, pendidikan, peradaban Islam 


\begin{abstract}
At around the world drowned in a stream of lies, loss of human dignity, far from the light of monotheism, and the social, political, economic, cultural and religious communities, especially the Arab world is very fragile and apprehensive, appears a major figure in the history of all time. He carried the torch of transformation from darkness into bright light of life. He led a chaotic society into a society that guided and educated, moreover released the Arab from polytheism to monotheism. He is the Prophet Muhammad who is well known as a carrier rahmatallil'alamin. The period of the Prophet Muhammad's leadership is a forerunner to the formation of Islamic civilization. The biggest crisis in the world today is a crisis exemplary. The crisis is more powerful than the energy, health, food, transportation and water crisis. Due to the absence of a visionary leader, competent, and have high integrity then the problem of water, forest conservation, health, education, justice system, and transport will be more severe. As a result, more and more day health care costs increasingly difficult to affordable, transportation management increasingly chaotic, the education lose conscience of compassion-oriented noble character, rivers and ground water increasingly polluted and garbage piled up everywhere. Here, among the problems experienced by the Muslim world, including Indonesia, as part of the world's third largest. Therefore, the leadership of the Prophet Muhammad is the benchmark that must be followed by all human beings in terms of projecting the pattern of leadership, because the leadership taught by him will lead people to be leaders who are respected, loved and followed by all people.
\end{abstract}

Keywords: leadership, education, Islamic civilization

\title{
Pendahuluan
}

Krisis terbesar di dunia saat ini adalah krisis keteladanan atau uswah. Krisis ini jauh lebih dahsyat dari krisis energi, kesehatan, pangan, transportasi dan air. Sebab, dengan absennya pemimpin yang visioner, kompeten, dan memiliki integritas yang tinggi, maka masalah air, konservasi hutan, kesehatan, pendidikan, sistem peradilan, dan transportasi akan semakin parah. Akibatnya, semakin hari biaya pelayanan kesehatan semakin sulit terjangkau, manajemen transportasi semakin amburadul, pendidikan semakin kehilangan nurani welas asih yang berorientasi kepada akhlak mulia, ${ }^{1}$

${ }^{1}$ Belum pernah kita mendengar ada suatu masa yang di situ pendidikan tidak dibicarakan. Ini di semua negara dan di semua waktu. Pendidikan merupakan masalah yang tidak pernah selesai (unfinished agenda). Pendidikan selalu terasa tidak pernah memuaskan. Pendidikan selalu dibicarakan. Pendidikan 
bahkan selalu menjadi bahan perdebatan. Apakah anda mengira pendidikan di Negara yang sudah maju tidak pernah lagi membicarakan pendidikan mereka? Apakah mereka sudah betul-betul puas terhadap pendidikan mereka? Tidak, orang-orang di Negara maju pun masih mengkritik keadaan pendidikan di Negara mereka. Mengapa demikian, manusia tidak pernah puas terhadap pendidikan yang ada. Semua orang ikut mengambil bagian bila yang dibicarakan pendidikan. Itu mudah dipahami. Karena semua orang berkepentingan dengan pendidikan. Orang yang ingin memperbaiki seseorang, sekelompok orang, suatu negara dan bahkan dunia, pasti akan melakukannya, langsung atau tidak langsung, melalui pendidikan. Orang yang akan merusak negara juga akan melakukan dengan melaui pendidikan. Jangan dikira para koruptor itu tidak pernah sekolah, pendidikan mereka umumnya justru tinggi. Orang yang mengerti pendidikan tentu juga ikut bicara masalah pendidikan. Orang yang tidak tahu apa-apa tentang pendidikan pun juga ikut andil untuk membicarakan pendidikan karena anak dan keturunannya telah dan akan mengikuti pendidikan. Pendidikan adalah masalah bersama, semua orang berkepentingan dengan pendidikan. Itulah sebabnya pendidikan tidak pernah selesai. Dan tidak pernah selesai dibicarakan dan orang tidak pernah puas dengan pendidikan hal itu karena sifat manusia yang tidak pernah merasa puas. Watak manusia yang tidak pernah puas pernah dibahas secara mendasar oleh J.P. Sartre, filosof eksistensial Perancis. Katanya, salah satu sifat dasar manusia ialah tidak pernah puas; yang ia inginkan ialah belum ada sedangkan yang ada bukanlah yang diinginkannya. Ini yang sudah menjadi takdir manusia, kata Sartre. Yang paling parah dalam pendidikan adalah kita sering kali menyaksikan perbaikan pendidikan secara tambal sulam. Misalnya, lulusan kurang cinta negara, lantas buru-buru pelajaran civic ditambah jamnya. Adakan pelatihan guru civic education. Orang melihat murid-murid malas shalat, orang buru-buru menambah jam pelajaran agama, penataran guru agama, mencetak buku paket. Namun yang luar biasa anehnya adalah saat korupsi sudah sangat meluas malah tidak ada respon atau reaksi apa-apa pada level pendidikan. Kalaupun ada sebatas wacana memunculkan pelajaran budi pekerti. Jelasnya baca Ahmad Tafsir, Filsafat Pendidikan Islami, (Bandung: Rosdakarya, 2006). Hal ini kenapa keteladan perlu di tingkatkan pada era sekarang karena pola pikir manusia masih tidak mampu meneladani dari sosok teladan yang baik (yaitu, Nabi Muhammad SAW), dalam hal ini Rasulullah SAW bersabda:

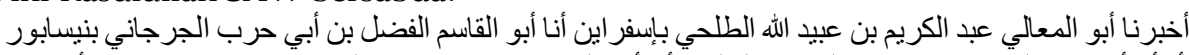

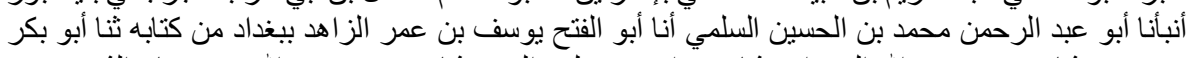

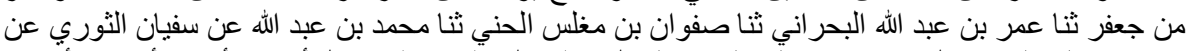

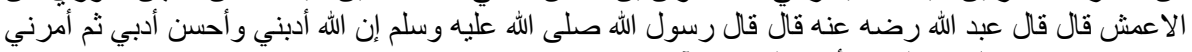

$$
\begin{aligned}
& \text { بمكارم الاخلاق فقال خذ العفو وأمر بالعرف الآية }
\end{aligned}
$$

"sesungguhnya Allah Telah mendidikku, dan ia membidikku dengan baik, kemudian ia menyuruhku dengan akhlak-akhlak mulia dan berfirman, Ambillah kemaafan dan suruhlah dengan kebaikan, serta berpalinglah dari orang-orang yang jahil". Jelasnya lihat di dalam kitab Adabul Imla' wa al-Istimla' karya Abdul Karim bin Muhammad bin Manshur Abu sa'id al-Tamimi al-Sam'ani (Beirut: Dar alKutub al-Ilmiyah), 6. (Hadits ini dinyatakan sahih oleh Abu al- I'adhl bin Nashir, dan dinyatakan dha'if oleh yang lainnya). 
sungai dan air tanah semakin tercemar dan sampah menumpuk di mana-mana inilah, antara lain, permasalahan yang dialami dunia muslim, termasuk Indonesia, sebagai bagian terbesar dari dunia ketiga. $^{2}$

Kepemimpinan adalah rangkaian kegiatan penataan berupa kemampuan mempengaruhi perilaku orang lain dalam situasi tertentu agar bersedia bekerjasama untuk mencapai tujuan yang ditetapkan. Dalam menjalankan kepemimpinannya, seorang pemimpin memiliki gaya-gaya tersendiri. Gaya (style) adalah suatu cara berperilaku yang khas dari seorang pemimpin terhadap para anggota kelompoknya. Kepemimpinan (leadership) adalah kemampuan yang harus dimiliki oleh seorang pemimpin (leader) tentang bagaimana menjalankan kepemimpinannya (to lead) sehingga bawahan dapat bergerak sesuai dengan yang diinginkan dalam mencapai tujuan yang ditetapkan sebelumnya.

Di zaman yang modern ini, kepemimpinan masih dianggap sebagai kekuatan utama dalam rangka merubah tatanan kebangsaan. Sesuai dengan visi dan misinya, misi abadi kepemimpinan adalah "pencerahan kehidupan bangsa" yang ditempuh melalui proses perubahan yang lebih objektif dalam pertautan zaman glamor ini.

Di Indonesia pada umumnya kekuasaan pemimpin dalam konteks personal power itu tidak akan berarti apa-apa untuk dapat menjelaskan bahwa kepemimpinan yang dijalankan efektif dalam mempengaruhi orang lain. Akan tetapi dibutuhkan personal behavior pemimpin dan keterampilan yang dijalankan efektif dalam mempengaruhi harus terangkum didalamnya bila kita menginginkan kelanjutan bagaimana pemimpin memengaruhi orang lain.

Kepemimpinan dalam konteks pendidikan makro dalam menyikapi tantangan globalisasi yang ditandai dengan adanya kompetisi global yang sangat ketat dan tajam, di beberapa negara telah berupaya untuk melakukan revitalisasi pendidikan. Revitalisasi ini termasuk pula dalam hal perubahan paradigma kepemimpinan pendidikan, terutama dalam hal pola hubungan atasan-bawahan, yang semula bersifat hierarkis-komando menuju ke arah kemitraan bersama. Pada hubungan atasan-bawahan yang bersifat hierarkiskomando, seringkali menempatkan bawahan sebagai objek tanpa daya. Pemaksaan kehendak dan pragmatis merupakan sikap dan

${ }^{2}$ Muhammad Syafi'i Antonio (Nio Gwan Chung), Muhammad SAW The Super Leader Super Manager, (Jakarta: Tazkia Multimedia \& ProLM Centre, 2008), 3. 
perilaku yang kerap kali mewarnai kepemimpinan komandobirokratik-hierarkis, yang pada akhirnya hal ini berakibat fatal terhadap terbelenggunya sikap inovatif dan kreatif dari setiap bawahan. Dalam melaksanakan tugas dan kewajiban, mereka cenderung bersikap a priori dan bertindak hanya atas dasar perintah sang pemimpin semata. Dengan kondisi demikian, pada akhirnya akan sulit dicapai kinerja yang unggul.

Menyadari semua itu, maka perubahan kebijakan kepemimpinan pendidikan yang dapat memberdayakan pihak bawahan menjadi amat penting untuk dilakukan. Larry Lashway mencetuskan tentang konsep Facilitative Leadership, ${ }^{3}$ yang pada intinya merupakan kepemimpinan yang menitikberatkan pada collaboration dan empowerment. Sementara itu, David Conley and Paul Goldman (1994) mendefinisikan facilitative leadership sebagai: "the behaviors that enhance the collective ability of a school to adapt, solve problems, and improve performance", ${ }^{4}$ kata kuncinya terletak pada collective. Artinya, keberhasilan pendidikan bukanlah merupakan hasil dan ditentukan oleh karya perseorangan, namun justru merupakan karya dari team work yang cerdas.

Pada tataran tersebut, kepemimpinan dapat mendorong seluruh bawahan dan seluruh anggota organisasi dapat memberdayakan dirinya, dan membentuk rasa tanggungjawab atas tugas-tugas yang diembannya. Kepatuhan tidak lagi didasarkan pada kontrol eksternal organisasi, namun justru berkembang dari hati sanubari yang disertai dengan pertimbangan rasionalnya. Seperti halnya pada model kepemimpinan fasilitatif tersebut yang merupakan alternatif model kepemimpinan yang dibutuhkan dalam dunia pendidikan guna menghadapi tantangan masa depan abad ke21, yang pada intinya model ini merujuk kepada upaya pemberdayaan setiap komponen manusia yang terlibat dan bertanggung jawab dalam pendidikan.

Kajian ini penulis beri judul: Formulasi Kepemimpinan Pendidikan (Perspektif Teori Kepemimpinan dalam Doktrin Islam). Upaya untuk mengetahui sejauh mana formulasi kepemimpinan

3 Larry Lashway, Leadership and Decision Making, Terj. David J. Lu, (Bandung: Remaja Rosdakarya, 1999), 97.

4 Herbert A. Simon, Perilaku Administrasi: Studi Tentang Pengambilan Keputusan Dalam Organisasi Administrasi, Terj. St. Dianjung, (Jakarta: Bina Aksara. 2001), 37. 
pendidikan yang ditinjau dalam sudut pandang atau kaca mata kepemimpinan Islam.

\section{Pembahasan \\ Teori Kepemimpinan Pendidikan}

Seringkali kita mendengar istilah kepemimpinan bahkan banyak pakar yang telah mengemukakan definisi kepemimpinan, tetapi tidak ada satu pun definisi yang diterima dengan pasti. Kepemimpinan dapat diartikan sebagai proses dan sebagai sifat-sifat yang dimiliki. ${ }^{5}$

Di sisi lain, banyaknya studi yang dilakukan tentang kepemimpinan, dan hasilnya adalah berupa rumusan, konsep, dan teori kepemimpinan. Studi dan rumusan kepemimpinan yang dihasilkan sangat dipengaruhi oleh paradigma dan pendekatan yang digunakan sehingga teori-teori yang di hasilkan mempunyai perbedaan dalam hal metodologi, pendapat dan uraiannya, penafsiran dan kesimpulannya. Dengan demikian rumusan yang perlu dihasilkan akan mengarah pada suatu teori konsep yang benarbenar memiliki kualitas terhadap eksistensi kepemimpinan yang ada dalam dunia pendidikan. ${ }^{6}$

Membincang pemimpin, berarti berbicara diri sendiri. Diri adalah entitas atau wujud otonom yang diciptakan Allah dalam dua demensi. ada demensi raga dan demensi jiwa (jasmani dan rohani). Dari dua unsur tersebut manusia telah menjadi pemimpin bagi dirinya sendiri. Jiwa akan menjadi pemimpin bagi jasadnya, sebab jiwa adalah suatu penggerak atau daya dari pada raga. Jiwa akan memberi komando pada raga. Di dalam jiwa terdapat banyak potensi-potensi ilahiyah yang akan mengantarkan manusia pada kepemimpinan pada dirinya, sedangkan jasad adalah organ yang terdiri dari bagian-bagian tertentu. Dari masing-masing organ tersebut akan bekerja sesuai dengan tugasnya masing-masing, mata akan bekerja untuk melihat, telinga untuk mendengar, mulut untuk berbicara dan banyak fungsi fungsi dari organ lainnya. ${ }^{7}$

5 Alo Liliweri, Ms. Wacana Komunikasi Organisasi, (Bandung: Mandar Maju, 2004), 151.

${ }^{6}$ Ara Hidayat dan Imam Machali, Pengelolaan Pendidikan: Konsep, Prinsip dan Aplikasi dalam Mengelola Sekolah dan Madrasah, (Bandung: Pustaka Educa, 2010), 86.

${ }^{7}$ Shoni Rahmatullah Amrozi, Menggagas Pemimpin Masa Depan, (Jember: Pena Salsabila, 2010), 4 . 
Dengan demikian kepemimpinan mencakup distribusi kekuasaan yang tidak sama di antara pemimpin dan anggotanya. Pemimpin mempunyai wewenang untuk mengarahkan anggota dan juga dapat memberikan pengaruh, dengan kata lain para pemimpin tidak hanya dapat memerintah bawahan apa yang harus dilakukan, tetapi juga dapat memengnaruhi bagaimana bawahan melaksanakan perintahnya. Sehingga terjalin suatu hubungan sosial yang saling berinteraksi antara pemimpin dengan bawahan, yang akhirnya tejadi suatu hubungan timbal balik. Oleh sebab itu, bahwa pemimpin diharapakan memiliki kemampuan dalam menjalankan kepemimpinannya, kareana apabila tidak memiliki kemampuan untuk memimpin, maka tujuan yang ingin dicapai tidak akan dapat tercapai secara maksimal.

Sehubungan dengan itu kalau kita rangkaikan dengan pengertian kepemimpinan diatas berarti kepemimpinan pendidikan adalah kemampuan yang dimiliki oleh seseorang dalam proses mempengaruhi, mendorong, membimbing, dan menggerakkan orang lain yang ada hubungannya dengan pelaksanaan dan pengembangan pendidikan dan pengajaran, agar segenap kegiatan dapat berjalan secara efektif dan efesien yang pada gilirannya dapat mencapai tujuan pendidikan dan pengajaran yang telah ditetapkan. Dengan ringkas dapat diungkapkan sebagai bantuan yang di berikan oleh seseorang tehadap penetapan dan pencaian tujuan pendidikan dan pengajaran.

Lembaga pendidikan membutuhkan seorang pemimpin. Sebab, pemimpin itulah sosok penggerak dan inspirasi dalam merancang dan mengerjakan kegiatan. Pemimpin dalam pendidikan tidak hanya seorang manajer, ia juga harus seorang pembangun mental, moral, spirit, dan kolektivitas kepada jajaran bawahannya. Seorang pemimpin sayogianya tidak hanya menggunakan aturan tertulis, tapi juga sikap prilaku, sepak terjang dan keteladanan dalam melakukan agenda transformasi kearah yang lebih baik. ${ }^{8}$ Berikut ini beberapa teori kepemimpinan.

Pertama, teori otokratis dan pemimpin otokratis. Pemimpin otokratis cendrung disebut otokrat keras. Pada intinya teori otokrat ini memiliki sifat-sifat yang tepat, seksama, sesuai dengan prinsip, namun keras dan kaku. Pemimpin tidak akan pernah

8 Jamal Ma'mur Asmani, Manajemen Pengelolaan dan Kepemimpinan Pendidikan Profesional: Panduan Quality Control bagi Para Pelaku Lembaga Pendidikan, (Jogjakarta: DIVA Press, 2009), 91. 
mendelegasikan otoritasnya. Lembaga atau organisasi yang dipimpinnya merupakan a one-man show. Karena dengan keras ia menekankan prinsip-prinsip Business is business atau dengan kata lain waktu adalah uang untuk bias makan, orang harus kerja keras, dan kecenderungan teori ini mengejar sesuatu kemenangan yang mutlak. Sikap dan prinsipnya sangat konservatif. Pemimpinnya akan bersikap baik terhadap orang-orang yang patuh serta loyal dan sebaliknya, disatu sisi dia akan bertindak keras dan sangat kejam terhadap bawahannya yang membangkan perintahnya. ${ }^{9}$

Kedua, teori psikologis. Teori ini menyatakan bahwa fungsi seorang pemimpin adalah memunculkan dan mengambangkan system motivasi terbaik, untuk merangsang bawahan agar mereka mau bekerja, guna untuk mencapai sasaran-sasaran organisatoris dan untuk memenuhi tujuan-tujuan pribadi. Oleh karena itu, pemimpin yang mampu memotivasi orang lain akan sangat mementingkan aspek-aspek psikis manusia, seperti pengakuan (recognizing), martabat, status social, kepastian emosional, memperhatikan keinginan dan kebutuhan pegawai, kegairahan kerja, minat, suasana, dan hati. ${ }^{10}$

Ketiga, teori sosiologis. Dalam teori ini, kepemimpinan dianggap sebagai usaha- usaha untuk melancarkan antar-relasi dalam organisasi atau lembaga, dan sebagai usaha untuk menyelesaikan setiap konflik organisatoris antara para pengikutnya. Agar tercapai kerja sama yang baik, pemimpin menetapkan tujuantujuan, dengan meyertakan para pengikut dalam pengambilan keputusan terakhir. Selanjutnya juga mengidentifikasi tujuan, dan kerap kali memberikan petunjuk yang diperlukan bagi para pengikut untuk melakukan setiap tindakan yang berkaitan dengan kepentingan kelompoknya. ${ }^{11}$

\section{Tipe dan Gaya Kepemimpinan Pendidikan}

Gaya artinya sikap, gerakan, tingkah laku, sikap yang elok, gerak-gerik yang bagus, kekuatan, kesanggupan untuk berbuat baik. Sedangkan tipe atau gaya kepemimpinan adalah sekumpulan cirri yang digunakan pimpinan untuk mempengaruhi bawahan agar sasaran organisasi tercapai. Dalam pengertian lain gaya

\footnotetext{
${ }^{9}$ Ara Hidayat dan Imam Machali, 86-87.

${ }^{10}$ Ara Hidayat dan Imam Machali, 87.

${ }^{11}$ Ara Hidayat dan Imam Machali, 87.
} 
kepemimpinan adalah pola prilaku dan strategi yang sering disukai dan sering diterapkan oleh seorang pemimpin.

Selanjutnya, gaya kepemimpinan adalah pola menyeluruh dari sebuah tindakan seorang pemimpin, baik yang tampak maupun yang tidak tampak oleh bawahannya. Gaya kepemimpinan menggambarkan kombinasi yang konsisten dari falsafah, keterampilan, sifat dan sikap yang mendasari prilaku seseorang. Gaya kepemimpinan yang menunjukkan secara langsung dan tidak langsung tentang keyakinan seorang pimpinan terhadap kemampuan bawahannya. Artinya, falsafah, keterampilan, sifat dan sikap yang sering diterapkan seorang pemimpin ketika ia mencoba mempengaruhi kinerja bawahannya. ${ }^{12}$

Terdapat beberapa gaya kepemimpinan sering juga disebut sebagai tipe kepemimpinan, di antaranya: Pertama, tipe lissez faire. Pada tipe kepemimpinan laissez faie ini sang pemimpin praktis tidak memimpin, dia memberikan kelompoknya dan setiap orang berbuat semaunya sendiri. Pemimpin tidak berpartisipasi sedikitpun dalam kegiatan kelompoknya. Semua tanggung jawab dan pekerjaan harus dilakukan oleh bawahan sendiri. Dia merupakan pemimpin simbol, dan biasanya tidak memiliki keterampilan teknis sebab duduknya sebagai direktur atau pemimpin-ketua dewan, komandan, atau kepala biasanya diperoleh melalui penyogokan, suapan atau sistem nepotisme. ${ }^{13}$

Kedua, tipe administratif atau eksekutif. Kepemimpinan tipe administratif ialah kepemimpinan yang mampu menyelenggarakan tugas-tugas administrasi secaa efektif. Sedangkan para pemimpinnya terdiri atas teknokrat dan administratus yang mampu menggerakkan dinamika modernisasi dan pembangunan. Dengan demikian, dapat dibangun sistem administrasi dan birokrasi yang efisian untuk pemerintah, yaitu untuk memantapkan integritas bangsa pada khususnya, dan usaha pembangunan pada umumnya. Dengan kepemimpinan administratif ini diharapkan adanya pekembangan teknis, yaitu teknologi, industri, manajemen modern dan perkembangan sosial di tengah masyarakat. ${ }^{14}$

Ketiga, tipe demokratis. Kepemimpinan demokratis berorientasi pada manusia, dan memberikan bimbingan yang efisien kepada pengikutnya. Terdapat kordinasi pekejaan pada semua

\footnotetext{
${ }^{12}$ Ara Hidayat dan Imam Machali, 89.

${ }^{13}$ Ara Hidayat dan Imam Machali, 90.

${ }^{14}$ Ara Hidayat dan Imam Machali, 90-91.
} 
bawahan, dengan penekanan kepada tanggung jawab internal (pada diri sendiri) dan kerja sama yang baik. Kekuatan kepemimpinan demokatis ini bukan terletak pada "person atau individu pemimpin", tetapi kekuatan justru terletak pada partisipasi aktif dari setiap kelompok.

Kepemimpinan demokratis menghargai potensi setiap individu dan mendengarkan nasihat dan sugesti bawahan. Juga bersedia mengakui keahlian para spesialis dengan bidangnya masing-masing. Mampu memanfaatkan kapasitas setiap anggota seefektif mungkin pada saat-saat kondisi yang tepat. Kepemimpinan demokatis sering disebut sebagai kepemimpinan group developer.

\section{Model Kepemimpinan Pendidikan}

Kepemimpinan Transformasional

Kepemimpinan transformasional dapat didefinisikan sebagai kemampuan seorang pemimpin dalam bekerja dengan atau melalui orang lain untuk mentransformasikan secara optimal sumber daya organisasi dalam rangka mencapai tujuan target capaian yang telah ditetapkan. Sumber daya yang dimaksud dapat berupa SDM, fasilitias, dana, dan faktor-faktor eksternal keorganisasian. Sadler mengungkapkan, "transformational leadership is the prosses of engaging the commitment of employees in the context of shared values and shared vision". Kepemimpinan transformasional adalah kepemimpinan dimana pemimpin mengembangkan komitmen pengikutnya dengan berbagi nilai-nilai dan visi organisasi. Dari pengertian tersebut ada tiga hal yang merupakan inti kepemimpinan transformasional, yaitu komitmen, berbagi nilai-nilai dan berbagi visi organisasi. Sementara itu, menurut Bass, "Transformational leadership contains four components: charisma or idealized influence (attributed or behavioral), inspirational motivation, intellectual stimulation, and individualized consideration.

\section{Kepemimpinan Visioner}

Kepemimpinan visioner (visionary leadership) adalah sebuah model atau pola kepemimpinan yang dimaksudkan memberi arti pada kerja dan usaha yang dilakukan secara bersama-sama oleh seluruh komponen organisasi dengan cara memberi arahan berdasarkan visi yang telah dibuat secara jelas.

Visi merupakan sebuah upaya untuk melakukan perubahan, yang mendorong terjadinya proses ledakan kreativitas melalui 
integrasi dan sinergi berbagai keahlian dari orang-orang yang ada dalam suatu lembaga atau organisasi tersebut. Aribowo Prijaksono dan Roy Sembel, sebagaimana dikutip oleh Rasto, mengatakan bahwa nothing motivates change more powerfully than a clear vision. Visi yang jelas dapat secara dahsyat mendorong terjadinya perubahan dalam sebuah organisasi. Visi inilah yang mendorong sebuah organisasi untuk senantiasa tumbuh dan belajar, serta berkembang dalam mempertahankan hidupnya. ${ }^{15}$

\section{Kepemimpinan Islam}

Kepemimpinan itu wajib ada, baik secara syar'i ataupun secara 'aqli. Adapun secara syar'i misalnya tersirat dari firman Allah tentang doa orang-orang yang selamat واجعلنا للمتقين إماما Aan jadikanlah kami sebagai imam (pemimpin) bagi orang-orang yang bertaqwa" (QS Al-Furqan : 74). "Taatlah kalian kepada Allah dan taatlah kalian kepada Rasul dan para ulul amri diantara kalian" (QS AnNisaa' : 59). ${ }^{17}$ Rasulullah saw bersabda dalam sebuah hadits yang sangat terkenal : "Setiap dari kalian adalah pemimpin, dan setiap dari kalian akan ditanya tentang kepemimpinannya". Terdapat pula sebuah hadits yang menyatakan wajibnya menunjuk seorang pemimpin perjalanan diantara tiga orang yang melakukan suatu perjalanan. Adapun secara 'aqli, suatu tatanan tanpa kepemimpinan pasti akan rusak dan porak-poranda.

Di sisi lain, seorang pemimpin merupakan khalifah (pengganti) Allah di muka bumi, maka dia harus bisa berfungsi sebagai kepanjangan tangan-Nya. Allah merupakan Rabb semesta alam, yang berarti dzat yang men-tarbiyah seluruh alam. Tarbiyah berarti menumbuhkembangkan menuju kepada kondisi yang lebih baik sekaligus memelihara yang sudah baik. Karena Allah mentarbiyah seluruh alam, maka seorang pemimpin harus bisa menjadi wasilah bagi tarbiyah Allah tersebut terhadap segenap yang ada di bumi. Jadi, seorang pemimpin harus bisa menjadi murabbiy bagi kehidupan di bumi.

${ }^{15}$ Rasto, “Kepemimpinan Visioner", Manajerial, Vol. 2, No. 3, Oktober 2003, $59-67$.

${ }^{16}$ Departemen Agama, Al-Qur'an dan Terjemah, (Jakarta: PT. Bumi Restu, 1974), 367.

${ }^{17}$ Ara Hidayat dan Imam Machali, 88. 
Dengan demikian, ada beberapa pemimpin yang termasuk kriteria pemimpin yang di gambarkan Allah SWT, diantanya adalah sosok Nabi Muhammad saw dan sahabat-sahabatnya.

Kepemimpinan Nabi Muhammad SAW.

Pada saat seluruh dunia tenggelam dalam arus kebohongan, kehilangan human dignity, jauh dari sinaran tauhid, dan keadaan sosial, politik, ekonomi, budaya dan agama masyarakat dunia khususnya Arab sangat rapuh dan memprihatinkan, muncul seorang tokoh besar dalam sejarah sepanjang masa. Beliau membawa obor transformasi dari kehidupan kegelapan menuju cahaya terang. Beliau mengantarkan masyarakat yang kacau menjadi masyarakat yang terbimbing dan terdidik, lebih-lebih melepaskan bangsa arab dari kemusyrikan menuju tauhid, beliau adalah Nabi Muhammad SAW yang terkenal sebagai pembawa risalah yang rahmatallil'alamin periode kepemimpinan Rasulullah SAW merupakan cikal bakal pembentukan peradaban Islam.

Michael H. Hart ${ }^{18}$ menjatuhkan pilihannya kepada Nabi Muhammad dalam urutan pertama daftar seratus tokoh yang berpengaruh di dunia. Hal ini mungkin mengejutkan sebagian kalangan umat manusia dan mungkin juga memunculkan tanda tanya kepada sebagian yang lain. Tapi dia berpegang pada keyakinannya dialah Nabi Muhammad satu-satunya manusia dalam sejarah yang berhasil meraih sukses-sukses luar biasa baik ditilik dari ukuran agama maupun ruang lingkup duniawi.

Selama tiga tahun Muhammad hanya menyebar agama terbatas pada kawan-kawan dekat dan kerabatnya. Baru tatkala memasuki tahun 613 M. dia mulai tampil di depan publik. Begitu dia sedikit demi sedikit punya pengikut, penguasa Mekkah memandangnya sebagai orang berbahaya, pembikin onar. Di tahun 622 M., cemas terhadap keselamatannya, Muhammad hijrah ke Madinah, kota di utara Mekkah berjarak 200 mil. Di kota itu dia ditawari posisi kekuasaan politik yang cukup meyakinkan.

Peristiwa hijrah ini merupakan titik balik penting bagi kehidupan Nabi. Dia susah memperoleh sejumlah kecil pengikut di Mekkah, sedangkan di Madinah pengikutnya makin bertambah sehingga dalam tempo cepat dia dapat memperoleh pengaruh yang menjadikannya seorang pemegang kekuasaan yang sesungguhnya.

${ }^{18}$ Michael H. Hart, Seratus Tokoh Paling Berpengaruh dalam Sejarah, Terj. H. Mahbub Djunaidi, (Jakarta Pusat: PT. Dunia Pustaka Jaya, 1978), 4. 
Pada tahun-tahun berikutnya sementara pengikut Muhammad bertumbuhan bagai jamur, serentetan pertempuran pecah antara Mekkah dan Madinah. Peperangan ini berakhir tahun 630 M. dengan kemenangan pada pihak Muhammad, kembali ke Mekkah selaku penakluk. Sisa dua setengah tahun dari hidupnya dia menyaksikan kemajuan luar biasa dalam hal cepatnya suku-suku Arab memeluk Agama Islam. Dan tatkala Muhammad wafat tahun 632 M., dia sudah memastikan dirinya selaku penguasa efektif seantero Jazirah Arabia bagian selatan.

Ditilik dari sudut jumlah dan ukuran, jelas Arab tidak bakal mampu menghadapinya. Namun, di medan pertempuran, pasukan Arab yang membara semangatnya dengan sapuan kilat dapat menaklukkan Mesopotamia, Siria, dan Palestina. Pada tahun 642 M. Mesir direbut dari genggaman Kekaisaran Byzantine, dan sementara itu balatentara Persia dihajar dalam pertempuran yang amat menentukan di Qadisiya tahun 637 M. dan di Nehavend tahun 642 M.

Tapi, penaklukan besar-besaran di bawah pimpinan sahabat Nabi dan penggantinya Abu Bakr dan Umar ibn al-Khattab, itu tidak menunjukkan tanda-tanda stop sampai di situ. Pada tahun 711 M., pasukan Arab telah menyapu habis Afrika Utara hingga ke tepi Samudera Atlantik. Dari tempat itu, mereka membelok ke utara dan menyeberangi Selat Gibraltar dan melabrak kerajaan Visigothic di Spanyol.

Sepintas lalu orang mesti mengira pasukan Muslim akan membabat habis semua Nasrani Eropa. Tapi pada tahun 732 M., dalam pertempuran yang masyhur dan dahsyat di Tours, satu pasukan Muslimin yang telah maju ke pusat negeri Perancis pada akhirnya dipukul oleh orang-orang Frank. Biarpun begitu, hanya dalam tempo secuwil abad pertempuran, orang-orang Bedewi ini dijiwai dengan ucapan-ucapan Nabi Muhammad - telah mendirikan sebuah empirium membentang dari perbatasan India hingga pasir putih tepi pantai Samudera Atlantik, sebuah empirium terbesar yang pernah dikenal sejarah manusia. Dan di mana pun penaklukan dilakukan oleh pasukan Muslim, selalu disusul dengan berbondongbondongnya pemeluk masuk Agama Islam.

Ternyata, tidak semua penaklukan wilayah itu bersifat permanen. Orang-orang Persia, walaupun masih tetap penganut setia Agama Islam, merebut kembali kemerdekaannya dari tangan Arab. Di Spanyol, sesudah melalui peperangan tujuh abad lamanya 
akhirnya berhasil dikuasai kembali oleh orang-orang Nasrani. Sementara itu, Mesopotamia dan Mesir dua tempat kelahiran kebudayaan purba, tetap berada di tangan Arab seperti halnya seantero pantai utara Afrika. Agama Islam, tentu saja, menyebar terus dari satu abad ke abad lain, jauh melangkah dari daerah taklukan. Umumnya jutaan penganut Islam bertebaran di Afrika, Asia Tengah, lebih-lebih Pakistan dan India sebelah utara serta Indonesia. Di Indonesia, Agama Islam yang baru itu merupakan faktor pemersatu. Di anak benua India, nyaris kebalikannya: adanya agama baru itu menjadi sebab utama terjadinya perpecahan.

Apakah pengaruh Nabi Muhammad yang paling mendasar terhadap sejarah ummat manusia? Seperti halnya agama-agama lain, Islam punya pengaruh luar biasa besarnya terhadap para penganutnya. Itu sebabnya mengapa penyebar-penyebar agama besar di dunia semua dapat tempat dalam buku ini. Jika diukur dari jumlah, banyaknya pemeluk Agama Nasrani dua kali lipat besarnya dari pemeluk Agama Islam, dengan sendirinya timbul tanda tanya apa alasan menempatkan urutan Nabi Muhammad lebih tinggi dari Nabi Isa ${ }^{19}$ dalam daftar. Ada dua alasan pokok yang jadi pegangan saya. Pertama, Muhammad memainkan peranan jauh lebih penting dalam pengembangan Islam ketimbang peranan Nabi Isa terhadap Agama Nasrani. Biarpun Nabi Isa bertanggung jawab terhadap ajaran-ajaran pokok moral dan etika Kristen (sampai batas tertentu berbeda dengan Yudaisme), St. Paul ${ }^{20}$ merupakan tokoh penyebar utama teologi Kristen, tokoh penyebarnya, dan penulis bagian terbesar dari Perjanjian Lama.

${ }^{19}$ Nabi Isa adalah seorang Nabi dan Rasul yang dipilih Allah SWT. Sebagai pemimpin untuk umatnya, beliau juga memiliki peran penting dalam metode kepemimpinannya, sehingga beliau mampu mengkondisikan umatnya serta mempengaruhinya untuk menuju ke jalan Allah SWT.

20 St. Paul dianggap Rasul di zamannya, dia sejaman tapi lebih muda sedikit dari Nabi Isa, tak asing lagi penyebar Agama Nasrani yang paling terkemuka. Pengaruhnya dalam teologi Kristen jelas menunjukkan yang paling mantap, paling berjangkau jauh dibanding semua penulis dan pemikir Kristen lainnya. Paul, juga terkenal dengan panggilan Saul, dilahirkan di Tarsus, sebuah kota di Cilicia, beberapa tahun sebelum tiba era Kristen. Biarpun seorang warga Romawi, dia lahir sebagai Yahudi, pendalam bahasa Ibrani di masa muda dan memperoleh pendidikan mendalam perihal ke-Yahudian, dia juga belajar dagang dan bikin kemah. Selaku pria remaja dia berangkat ke Darussalam bekerja di bawah bimbingan pendeta Gamaliel, seorang guru Yahudi kenamaan. Walaupun Paul dan Isa berbarengan ada di Darussalam saat itu, tapi amat diragukan keduanya pernah bertemu muka. 
Sebaliknya, Muhammad bukan saja bertanggung jawab terhadap teologi Islam tapi sekaligus juga terhadap pokok-pokok etika dan moralnya. Tambahan pula dia "pencatat" Kitab Suci AlQuran, kumpulan wahyu kepada Muhammad yang diyakininya berasal langsung dari Allah. Sebagian terbesar dari wahyu ini disalin dengan penuh kesungguhan selama Muhammad masih hidup dan kemudian dihimpun dalam bentuk yang tak tergoyangkan tak lama sesudah dia wafat. Al-Quran dengan demikian berkaitan erat dengan pandangan-pandangan Muhammad serta ajaran-ajarannya karena dia bersandar pada wahyu Tuhan. Sebaliknya, tak ada satu pun kumpulan yang begitu terperinci dari ajaran-ajaran Isa yang masih dapat dijumpai di masa sekarang. Karena Al-Quran bagi kaum Muslimin sedikit banyak sama pentingnya dengan Injil bagi kaum Nasrani, pengaruh Muhammad dengan perantaraan Al-Quran teramatlah besarnya. Kemungkinan pengaruh Muhammad dalam Islam lebih besar dari pengaruh Isa dan St. Paul dalam dunia Kristen digabung jadi satu. Diukur dari semata mata sudut agama, tampaknya pengaruh Muhammad setara dengan Isa dalam sejarah kemanusiaan.

Ini jelas menunjukkan beda besar dengan penaklukan yang dilakukan oleh bangsa Arab. Membentang dari Irak hingga Maroko, terbentang rantai bangsa Arab yang bersatu, bukan semata berkat anutan Agama Islam tapi juga dari jurusan bahasa Arabnya, sejarah dan kebudayaan. Posisi sentral Al-Quran di kalangan kaum Muslimin dan tertulisnya dalam bahasa Arab, besar kemungkinan merupakan sebab mengapa bahasa Arab tidak terpecah-pecah ke dalam dialek-dialek yang berantarakan. Jika tidak, boleh jadi sudah akan terjadi di abad ke-13. Perbedaan dan pembagian Arab ke dalam beberapa negara tentu terjadi -tentu saja- dan nyatanya memang begitu, tapi perpecahan yang bersifat sebagian-sebagian itu jangan lantas membuat kita alpa bahwa persatuan mereka masih berwujud. Tapi, baik Iran maupun Indonesia yang kedua-duanya negeri berpenduduk Muslimin dan keduanya penghasil minyak, tidak ikut bergabung dalam sikap embargo minyak pada musim dingin tahun 1973 - 1974. Sebaliknya, bukanlah barang kebetulan jika semua negara Arab, semata-mata negara Arab, yang mengambil langkah embargo minyak.

Jadi, dapatlah kita saksikan, penaklukan yang dilakukan bangsa Arab di abad ke-7 terus memainkan peranan penting dalam sejarah ummat manusia hingga saat ini. Dari segi inilah saya menilai 
adanya kombinasi tak terbandingkan antara segi agama dan segi duniawi yang melekat pada pengaruh diri Muhammad sehingga saya menganggap Muhammad dalam arti pribadi adalah manusia yang paling berpengaruh dalam sejarah manusia. ${ }^{21}$

Yang paling menarik dari pemerintahan yang di pimpin Nabi Muhammad SAW di Madinah adalah memberi kemerdekaan individu, kebebasan beragama hak sebagai warga social dan Negara, juga kedaulatan di tangan Allah dan diakui Nabi berkuasa penuh sebagai pemimpin, atau istilah lain dari pemerintahan di Madinah Allah memiliki de jure sovereignty, sedangkan Nabi Muhammad memiliki de facto sovereignty. Hal ini yang menjadi ciri khas tersendiri dari kepemimpinan Nabi Muhammad pada saat itu. Dengan demikian, banyak hal yang diperoleh dan berdampak positif dari cri khas kepemimpinan beliau diantaranya adalah adanya sebuah sekretariat Negara, adanya sumbe-sumber pendapatan negara (ghanimah, zakat, jizyah ${ }^{22}$, kharaj ${ }^{23}$ ), dan al-fay, departemen kehakiman dan sebagainya. ${ }^{24}$ Hal yang paling menarik lainnya adalah sebagai seorang muslim tentunya kita mengidealkan sosok Nabi Muhammad, beliau memiliki sifat siddiq, amanah, tabligh, dan fathanah, keempat sifat tersebut yang membekali nabi Muhammad SAW. ${ }^{25}$

${ }^{21}$ Michael H. Hart, 32.

${ }^{22}$ Al- Jizyah berasala dai bahasa Persia dari kata Gezit, dan dari istilah Romawi (Bizantium) berasal dari kata Tributum Crapitis, keduanya merupakan pajak yang ditarik sebagai pajak keamanan, sedangkan pada zaman Islam hanya di ambil dari laki-laki dewasa non muslim, apabila dia ikut perang maka ia terbebas dari jizyah, hasil dari pengumpulan pajak tersebut dialokasikan pada pos-pos untuk gaji, pakaian, makanan dan peralatan ketentaraan. (Husaini, Arab, hlm.2627). Seperti terjadi pada masa Umar I, Hims, Damaskus di Syam tidak bias dipertahankan lagi karena tentaranya ditarik untuk menghadapi perang irak melawan Pesia dalam pimpinan Saa Ibn Qaqqas, dengan demikian harta rampasan yang telah ditarik dari rakyat dikembalikan. Lihat M. Abdul Karim, Sejarah Pemikiran dan Peadaban Islam, (Yogjakarta: Pustaka Book Publisher, 2007), 163.

${ }^{23}$ Al-Kharaj adalah pajak tanah bagi non muslim yang dibayarkan kepada Negara sebesar lima puluh persen. Dalam bahasa Persia kharag, sedangkan dari Bizantium berasal dari bahasa Tributum Soli. Ketika Nabi Muhammad menaklukan Khaibar oang muslim tidak memiliki tenaga yang menandai untuk mengerjakan sawah, maka Nabi mempekerjakan non-muslim, dengan imbalan lima puluh pesen mereka membayar kepada Negara.

${ }^{24}$ M. Abdul Karim, 74.

${ }^{25}$ Shoni Rahmatullah Amrozi, 14. 


\section{Simpulan}

Kepemimpinan pendidikan pada hakikatnya adalah berkhidmat atau menjadi pelayan umat. Kepemimpinan yang asalnya adalah hak Allah SWT di berikan kepada manusia sebagai khalifah Allah SWT di muka bumi. Jika bukan karena kehendak-Nya, tidak ada seorangpun yang mendapatkan amanah kepemimpinan, baik kecil maupun besar. Oleh karena itu, setiap amanah kepemimpinan harus dipertanggung jawabkan di hadapan Allah SWT. Allah memberikan amanah kepada seorang pemimpin untuk (1) mengatur urusan orang yang dipimpinnya (2) mengarahkan perjalanan sekelompok manusia yang dipimpinnya guna mencapai tujuan bersama (3) menjaga dan melindungi kepentingan yang dipimpinnya. Wewenang dan kekuasaan yang diberikan kepada seorang pemimpin tidaklah ringan di mata Allah. Meskipun seringkali godaan setan dengan iming-iming keuntungan dunia telah memalingkan motivasi para pemimpin dari tujuan bersama.

Sebagai suprastruktur dari Kepemimpinan Islam tidak lepas dari sistem, dan perangkat lunak lainnya. Oleh karenanya perangkat lunak yang akan menjadi proyek dalam rangka pembaharuan harus diformulasikan dengan jelas. Hal tersebut tentunya sesuai dengan keteladanan dari teladan terbaik sepanjang masa yang harus di aktualisasikan dalam berkiprah untuk menyongsong kepemimpinan Islam lebih baik di masa yang akan datang.

\section{Referensi}

Amrozi, Shoni Rahmatullah. Menggagas Pemimpin Masa Depan. Jember: Pena Salsabila, 2010.

Ara Hidayat dan Imam Machali. Pengelolaan Pendidikan "Konsep, Prinsip dan Aplikasi dalam Mengelola Sekolah dan Madrasah. Bandung: Pustaka Educa, 2010.

Arifin. Penelitian Kualitatif dalam Ilmu-Ilmu Sosial dan Keagamaan. Malang: Kalimasahada Press, 1996.

Asmani, Jamal Ma'mur. Manajemen Pengelolaan dan Kepemimpinan Pendidikan Profesional: Panduan Quality Control bagi para pelaku Lembaga Pendidikan. Jogjakarta: DIVA Press, 2009.

Bush, Tony dan Marianne Coleman. Manajemen Strategis Kepemimpinan Pendidikan: Seri Manajemen Mutu Pendidikan. Terj. Fahrurrozi. Yogjakarta: IRCisoD, 2010. 
Chadwick dkk. Metode Penelitian Ilmu Pengetahuan Sosial. Semarang: IKIP Semarang Press. 1991.

Departemen Agama. Al-Qur'an dan Terjemah. Jakarta: PT. Bumi Restu, 1974.

Hart, Michael H.. Seratus Tokoh Paling Berpengaruh Dalam Sejarah. Terj. H. Mahbub Djunaidi. Jakarta Pusat: PT. Dunia Pustaka Jaya, 1978.

Karim, M. Abdul. Sejarah Pemikiran dan Peradaban Islam. Yogjakarta: Pustaka Book Publisher, 2007.

Lashway, Larry. Leadership And Decision Making. Terj: David J. Lu. Bandung: Remaja Rosdakarya. 1999.

Liliweri, Alo. Wacana Komunikasi Organisasi. Bandung: Mandar Maju, 2004.

Manullang, M. Dasar-dasar Manaemen. Yogyakarta: Gadjah Mada University Press, 2008.

Mulyono. Manajemen Administrasi dan Organisasi Pendidikan. Jogjakarta: Ar- Ruzz Media, 2009.

Nasution, M.N. Manajemen Mutu Terpadu: Total Quality Management. Bogor Selatan: Ghalia Indonesia, 2004.

Rasto, “Kepemimpinan Visioner", Manajerial, Vol. 2, No. 3, Oktober 2003, 59-67.

Simon, Herbert A. Perilaku Administrasi: Studi Tentang Pengambilan Keputusan dalam Organisasi Administrasi. Terj. St. Dianjung. Jakarta: Bina Aksara, 2001.

Soepono. Metodologi Penelitian Kualitatif. Jakarta: Rineka Cipta, 2004. 